
ISSN : 2615-1995, E-ISSN : 2615-0654

J. Madani., Vol. 2, No. 2, September 2019 (216 - 231)

C2018 Lembaga Kajian Demokrasi

MADANI

dan Pemberdayaan Masyarakat (LKD-PM)

\title{
Kualitas Pelayanan dan Kepuasan Pelanggan Pada Bank Syariah " $X$ " Dengan Menggunakan Model Carter
}

\author{
Eko Cahyadi \\ Fakultas Ekonomi, Universitas Pamulang \\ dosen02030@unpam.ac.id
}

\begin{abstract}
Abstrak
Penelitian ini memiliki tujuan bagaimana menilai kualitas pelayanan (service quality) dan kepuasan pelanggan (customer saticfaction) pada industri perbankan syariah dengan menggunakan metode CARTER di era persaingan yang semakin ketat. Produk inovasi (inovation product) serta Persaingan dalam merebut pasar yang sama dan mendapatkan customer satisfaction merupakan pekerjaan sehari-hari perusahaan perbankan. Penelitian ini bertujuan untuk meneliti dan mengkaji mengenai pelayanan pelanggan yang memberikan kepuasan kepada pelanggan sehingga akan membuat dan memberikan pelanggan yang setia pada produk yang kita tawarkan. Penelitian ini adalah penelitian deskriptif analitis menggunakan pendekatan kuantitatif. Dalam penelitian in dilakukan secara cross sectional yaitu dengan mengumpulakan data melalui field study atau studi lapangan, data primer didapatkan dengan penyebaran kuestioner dan data sekunder dengan kajian literature. Berdasarkan analisa tingkat kualitas pelayanan dan kepuasan pelanggan dilihat dari faktor-faktor yang diteliti dalam tiap dimensi CARTER (Compliance atau pemenuhan prinsip syariah, Assurance atau jaminan, Reliability atau keandalan, Tangible atau wujud, Emphaty atau empati dan Responsiveness atau responsif. Penelitian ini menyatakan bahwa sebagian besar nasabah melihat bahwa bank syariah " $X$ " memberikan pelayanan yang dikategorikan berkualitas. Walaupun demikian nasabah merasa bahwa pelayanan yang bank syariah " $X$ berikan atau lakukan belum dapat memuaskan nasabah. Kedepannya bank syariah "X"harus meningkatkan kinerja pelayanan kepada nasabahnya. Peningkatan ini dapat dilakukan dengan me-upgrade teknologinya dan masuk ke digital banking sehingga bisa bersaing dengan bank lain termasuk bank syariah maupun konvensional. Selain itu bank syariah " $X$ ' perlu melakukan pelatihan-pelatihan kepada karyawannya dalam meningkatkan kualitas pelayanan kepada nasabahnya.
\end{abstract}

Kata Kunci : Kualitas Pelayanan, Kepuasan Pelanggan, Bank Syariah

\begin{abstract}
This study aims to assess service quality and customer satisfaction in the sharia banking industry by using the CARTER method in an era of increasingly fierce competition. Product innovation (product innovation) and competition in seizing the same market and gaining customer satisfaction are the daily work of banking companies. This study aims to examine and assess customer service that gives satisfaction to customers so that it will make and provide customers who are loyal to the products we offer. This research is analytical descriptive research using a quantitative approach. In this study conducted by cross sectional, namely by collecting data through field studies or field studies, primary data was obtained by distributing questionnaires and secondary data with literature review. Based on the analysis of the level of service quality and customer satisfaction seen from the factors examined in each dimension of CARTER (Compliance or fulfillment of sharia principles, Assurance, Reliability, Tangibility, Empathy and Responsiveness. This research states is the Islamic bank " $X$ " that provides services that are categorized as quality. However, customers feel that services provide have not
\end{abstract}


been able to satisfy customers. In the future Islamic banks" $X$ "must improve service performance to their customers by upgrading the technology and entering into digital banking so that it can compete with other banks including Islamic and conventional banks. In addition, Islamic banks " $\mathrm{X}$ " need to conduct training for their employees in improving the quality of service to their customers.

\section{Keywords : Service Quality, Customer Satisfaction, Islamic Bank}

\section{PENDAHULUAN}

\section{Latar Belakang}

Keberadaan perbankan syariah di tanah air sejak tahun 1992 secara formal setelah terbitnya dan diberlakukannya UU no.7 tahun 1992, dan saat ini tumbuh pesat dan semakin memiliki persaingan yang ketat. Dalam mengembangkan kualitas pelayanan didorong oleh kondisi persaingan yang terjadi antar perusahaan, perkembangan cepat teknologi, proses perekonomian dan history atau sejarah perkembangan masyarakat. Kita bisa melihat begitu banyaknya tawaran yang sama bahkan tidak ada perbedaan baik dari perbankan nasional maupun internasional. Hal ini dilakukan untuk dapat memuaskan pelanggan. Peluang-peluang bagi inovasi serta pengembangan pelayanan yang sangat masif didorong oleh teknologi. Pada saat yang sama masyarakat semakin sejahtera sehingga mendorong tawar-menawar yang memiliki kualitas lebih. Pada sisi masyarakat mengalami perubahan historis, yaitu masyarakat yang sedang beralih menjadi masyarakat yang berbasiskan pada pengetahuan (society knowledge economy).

Ada 2 kekuatan yang mendorongnya akan muncul. Pertama, makin menitikberatkan pada menggali dan menggunakan teknologi yang telah diketahui dan ada. Kedua, akan lebih efektif memilih teknologi baru yang kiranya memberikan hasil peotensial yang terbesar dalam memecahkan masalah nasabah.

Pemasaran barang dan jasa pasti berbeda sekali, karena pemasaran jasa abstak atau intangible yang tidak bisa jelas dilihat secara kasat mata dan hal ini sesuai dengan karakteristiknya. Bila produk kita bisa lihat baranya dan spesifiknya, Sedangkan jasa sulit untuk diidentifikasi. Jasa baru bisa dipahami dan dapat diidentifikasi pada saat dikaitkan dengan hubungan langsung atau interpersonal seperti hubungan produsen dan konsumen. Proses menerima dan memberi ini yang diukur dengan tingkat kepuasaan sehingga memiliki sifat subjektif. Subjektif ini bergantung sekali pada siapa yang melakukan perbuatan jasa dan siapa yang menerima atau menggunkana jasa tersebut. Dengan dasar ini pemasaran jasa walaupun namanya sama tetapi sebetulnya berbeda tergantung jenis jasa yang menggunakan objek.

Jasa dapat dibedakan menjadi dua kelompok. Pertama adalah jasa yang lebih banyak menggunakan tenaga peralatan dan kedua adalah jasa yang lebih banyak menggunakan tenaga manusia. jasa yang lebih banyak menggunakan tenaga peralatan misalnya telekomunikasi dan perbankan. Akibatnya disanabisa dihasilkan standarisasi untuk mengukur kepuasan dan keberhasilan. Walaupun demikian satu cabang dengan cabang yang lainnya memiliki tingkat pelayanan yang berbeda-beda. Sedangkan jasa yang lebih banyak menggunakan tenaga manusia perbedaan jauh lebih besar. Sehingga mutu pelayanan dilihat dari si pemakai jasa. Contoh, pelayanan yang diberikan oleh praktek bersama yang dilakukan oleh dokter, berbeda-beda. Jadi interpersonalnya lebih besar pada jasa yang menggunakan tenaga manusia. Selain itu jasa yang lebih banyak menggunakan tenaga manusia tuntutan kepada managernya adalah bagaiman menggunakan tenaga profesional dengan pemberian pelayanan yang lebih standar. Dengan kata lain diupayakan terlalu jauh, itulah yang terdapat di beberapa pelayanan seperti notaris, akuntan, dan konsultan.

Bila dilihat dari segi produk untuk mengidentifikasi jasa agak sulit, begitupun kalau dilihat dari segi penyaluran, sifatnya langsung sehingga antara produksi, konsumsi dengan deliverinya terdapat pada saat dan waktu yang sama. Kemudian kalau dilihat dari harga didasarkan pada satu tingkat risiko dari hanya inefisiensi dalam menggunakan peralatan. Dari segi 
promosi jasa juga bersifat interpersonal. Pengguna jasa biasanya memberikan informasi dengan jalan mulut ke mulut (hal ini lebih efektif sebab kalau sesekali terdapat kesalahan akibat jasa yang diberikan kurang baik, itu akan besar pengaruhnya terahadap pandangan konsumen).

Jasa biasa dilihat sebagai sesuatu fenomena komplek atau rumit. Jasa itu sendiri dapat diartikan dari awal pelayanan personal (personal service) sampai menjadi sebuah atau suatu produk. Sampai saat ini sudah banyak ahli pemasaran jasa yang mendefinisikan pengetian jasa diantaranya Valerie A Zeithaml serta Mary j Bitner pada tahun 1996, beliaumendeskripsikanserviceis alleconomic activities whose output is not a physicalproduct or contruction is generally consumed at that time it is produced, and provides added value in form (such as convenience, emusement, comfort or health). Philip Kohter mmbedakan empat kategori yang bervariasi dari jenis barang murni sampai dengan jasa murni.

Produk barang atau barang murni contohnya adalah seperti pembersih badan atau sabun, odol atau pasta gigi, atau gula, jenis barang ini tidak ada jasa yang melengkapi produk tersebut. Produk dengan fisik ditambah dengan jasa pelengkap yang dapat meningkatkan ketertarikan konsumen seperti motor, komputer, mobil. Jasa Utama adalah jasa yang dijual disertai dengan barang seperti usaha taksi, penerbangan dengan menggunakan kelas satu. Selanjutnya jasa murni adalah jasa yang tidak berhubungan dengan baik peralatan atau produk menunjang lainnya seperti pengasuh bayi atau psikologi.

Jasa memiliki karakterisitk yang unik yang membedakannya dari barang hasil dari proses manufaktur (produk). Empat karakter atau cirriciri yang paling banyak dijumpai dalam jasa adalah sebagai berikut:

Intangible (tidak berwujud), jasa bersifat abstrak dan tidak berwujud, jasa tidak terlihat, tidak bisa dirasakan sebelum dikonsumsi. Karena itulah, pembeli harus memiliki keyakinan yang tinggi kepada penjual jasa, dipihak lain penjual harus berusaha agar dapat ditingkatkan wujud jasa yang diberikan kenasabah sehingga terlihat manfaat dari jasa tersebut.
Heterogenitas, Jasa merupakan variable non standard dan sangat bervariasi yaitu sangat bergantung sekali kepada siapa yang memberikannya, waktu pelayanannya kapan dan tempat diberikannya dimana layanan jasa tersebut. Untuk contoh misalnya tarip notaris setelah mereka melakukan layanan kenotariatan. Hal ini akan berbeda jika dibandingkan disetiap kota seperti Jakarta, Bandung, Medan serta kota kecil, termasuk dalam hal ini adalah tarif notaris, pengacara.

Karakter jasa selanjutnya yaitu menyatu atau tidak terpisah, umumnya jasa dihasilkan dan digunakan pada satu waktu yang sama atau bersamaan, keterlibatan konsumen pada proses tersebut jasa akan selalu melekat pada orang yang memberikannya atau penjualnya. Pasien misalnya akan terus konsultasi dengan dokter langganannya dan bisa jadi ia tidak puas bahkan kecewa pada saat dokter tersebut digantikan oleh dokter lainnya ditempat prakteknya.

Jasa memiliki waktu yang tidak tahan lama, jasa akan habis pakai atau tidak mungkin disimpan dalam persediaan seperti halnya produk secara fisik. Jasa akan menampakkan nilainya disaat pembeli jasa menerima pelayanan yang dibutuhkan oleh sebab itu banyak sekali permintaan akan jasa tidak stabil atau berfluktuasi. Hal ini dapat dilihat pada jasa angkutan umum seperti waktu pagi hari atau sore hari pada saat jam berangkat dan pulang kantor/sekolah akan tinggi, dan pada saat diluar waktu pagi dan sore akan mengalami penurun tajam permintaannya.

Persaingan perbankan syariah saat ini dibilang sudah sedemikian ketat dalam menaklukkan pasar, produk yang inovatif, pelayanan yang memberikan customer satisfaction merupakan pekerjaan sehari perusahan perbankan. Apalagi hal ini tidak bisa dianggap kecil karena bila mereka tidak puas maka mereka akan pindah ke pesaing. Bila nasabah adalah penonton yang merupakan tamu kita, maka mereka sedang mengendalikan kita karena dengan gampang memilih pengalaman atau cerita yang mereka lihat, ibarat sebuah kumbang jika ada bunga yang lebih harum, madu yang lebih manis dan banyak, dengan kata lain si kumbang hanya mau menjambangi bunga yang 
sesuai dengan specification dan expectation-nya saja. Sehingga bank syariah sebagai aktor yang bermain dalam sandiwara dan layaknya pemainpemain yang harus memberikan pengalaman yang menyenangkan (delightful experience) kepada penonton yaitu pelanggan kita. Seperti kita ketahui bahwa menjaga nasabah yang telah memakai produk kita dan puas lebih menguntungkan dibandingkan dengan merebut nasabah dari kompetitor. Semakin mereka terpuaskan semakin makin besar keuntungan yang kita dapat.

Untuk mewujudkan customer satisfaction atau kepuasan pelanggan, barang-barang ataupun jasa yang dijual oleh perusahaan ke pelanggan wajib berkualitas. Kualitas sendiri memiliki arti berbagai macam arti dimana yang sederhana, kualitas bisa digambarkan sebagai produk tanpa kesalahan. Kemudian pemahaman terkait kualitas di perluas menjadi seusian sesuai dengan kegunaan (fitness for use) dan respon akan fungsi (conformance to requirement) (Gregorious,2002). Kualitas menggambarkan segala macam dimensi dari apa yang ditawarkan oleh produk sehingga memberikan nilai atau manfaat bagi nasabah, istilah manfaat atau sering diartikan nilai (value) banyak sekali dipakai untuk menerangkan atau dikaitkan antara kualitas relatif dengan harga jual produk.

Pelayanan yang dilakukan secara menyeluruh (total quality service) adalah sistem yang masuk kedalam strategi manajemen serta terintegrasi dimana melibatkan seluruh daya potensi secara maksimal, seperti keterampilan, kerja sama tim, fasilitas, sarana dan prasarana, informasi dan modal. Pelayanan yang dilakukan secara menyeluruh ini menggunakan cara kualitatif dan kuantitatif dalam memperbaiki setiap proses operasional perusahaan secara berkelanjutan sehingga mempu memenuhi dan melampaui keinginan serta harapan pelanggan seperti yang di sampaikan Freddy Rangkuti.

Sesungguhnya bisa dikatakan sulit untuk mendefinisikan terkait kualitas secara tepat, pada umumnya kualitas bisa di jabarkan. Total Quality Management (TQM) memiliki cara pandang tidak sempit atau luas dimana bukan aspek hasil saja yang ditekankan, melainkan tapi juga ter- masuk proses, lingkungan dan manusia. Kualitas adalah kondisi dinamis yang terhubung dengan produk, proses, jasa, manusia serta kondisi yang memenuhi keinginan dan melebihi harapan nasabah.

Usaha dalam mengembangkan perbankan syariah masih banyak ditemui sejumlah tantangan permasalahan yang perlu dislesaikan, baik jangka pendek, menengah maupun jangka panjang. Sistem operasi dan produk-produk layanan perbankan syariah dapat merupakan alternatif yang memadai dalam memperkaya jasa pelayanan perbankan yang ada dan dalam beberapa keadaan perbankan syariah dapat menunjukkan kinerja yang baik. Walaupun begitu kontribusi perbankan syariah masih sangat rendah dibandingkan dengan total industri keuangan secara nasional. Beberapa kendala masih harus diatasi, baik berupa infrastruktur seperti peraturan perundang-undangan dan perangkat hukum lainnya, istrumen keuangan syariah yang dapat diperjualbelikan dipasar keuangan dan hambatan dalam proses sosialisasi serta masalahmasalah sumber daya insani.

Pengembangan bank syariah memerlukan perhatian kualitas yang menyeluruh (total). Pencapaian pengembangan perbankan syariah yang berhasil sangat ditentukan oleh kemampuan dari bank-bank syariah dalam melakukan excellent service pada saat melayani masyarakat yang membutuhkan produk dan jasa perbankan syariah. Sehinga kedepannya bank syariah tidak hanya mengedepankan ke halal produk semata, tetapi juga harus mempu memberikan kualitas pelayanan yang dapat memuaskan nasabahnya. Sehingga bisa bersaing dengan bank konvensional.

Pelanggan dan perusahaan pada dasarnya membicarakan hal yang sama apakah itu produk, jasa, atau brand. Namun, mereka memiliki dua cara pandang yang berbeda sama sekali sehingga dapat menimbulkan gap. Perusahaan sangat concern dengan hal teknis yang dapat memenuhi kepuasan pelanggan namun pelanggan tidak perduli sama sekali. Kondisi ini terjadi karena kurangnya tranparansi dari bank dan belum berpikir dari sisi pelanggan menurut hermawan kertajaya.

Awal dari kualitas dimulai dari kebutuhan 
pelanggan dan berakhir pada persepsi pelanggan menurut Kohler (1994). Hal ini menandakan jika penampakan kualitas yang baik tidak didasarkan dari sudut pandang atau persepsi pihak bank atau penyedia jasa, melainkan sesuai sudut pandang atau persepsi pelanggan. Nasbah atau pelangganlah yang menggunakan dan merasakan jasa perusahaan. Sehingga nasabahlah yang seharusnya menilai dari kualitas jasa yang diberikan. Persepsi pelanggan akan kualitas jasa adalah penilaian dari keseluruhan atau keunggulan suatu jasa yang diberikan. Perlu menjadi perhatian bahwa kinerja seringkali labil/tidak konsisten. Pada kondisi ini pelanggan bisanya memberikan isyarat intrinsik dan ekstrinsik jasa sebagai acuan agar dipenuhi oleh bank. Tanda-tanda isyarat intrinsic berkaitan dengan output dan cara menyampaiakan jasa tersebut. Sedangkan tanda-tanda ekstrinsik adalah unsur-unsur yang melengkapi jasa tersebut.

Kualitas pelayanan fokus pada evaluasi yang merefleksikan persepsi pelanggan dengan dimensi yang khusus. Dalam kaitan pemasaran jasa, ada 5 (lima) dimensi yang paling sering menjadi acuan dalam menilaikualitas pelayanan yaitu kehandalan (reliability), responsif (responsiveness), jaminan (assurance), empati (emphaty), wujud (tangibles) dan penerapan penuh prinsip dan hukum syariah (compliance). Dalam penelitian ini didapat 1 dimensi yaitu compliance untuk mengukur penerapan hukum dan prinsip syariah dalam perbankan syariah. Kualitas pelayanan fokus pada evaluasi yang berarti lebih terbuka. Keterbukaan ini dipengaruhi oleh persepsi dari kualitas pelayanan, produk, kualitas, harga sebanding dengan faktor situasi dan faktor individu.

Ketika tertuju ke persepsi pelanggan, kita menduga bahwa dimensi jasa dan cara pelanggan mengevaluasi jasa sama antara eksternal dan internal pada perusahaan. Pelanggan eksternal dapat dipahami adalah konsumen pribadi atau konsumen untuk dijual kembali. Pelanggan internal adalah Karyawan dalam perusahaan dimana pekerjaannya tergantung pada perusahaan untuk menyediakan barang dan jasa.

Kualitas pelayanan yang didapat oleh pelanggan bisa menemukan kinerja yang dilakukan memiliki persepsi yang berkualitas yang memiliki dampak kepada kepuasan pelanggan. Secara empiris sejumlah penelitian menerangkan bahwa kualitas yang tinggi memiliki dampak pada kinerja suatu bisnis secara signifikan. Kepuasan tinggi akan memperlihatkan tingkat kepuasan pelanggan yang tinggi juga.

Bila kita membicarakan kualitas produk baik barang dan juga jasa, pada kepuasan telah tercapai kondisi bahwa harapan pelanggan sangat berperan besar sebagai acuan dalam melakukan evaluasi kualitas maupun kepuasaan. Menurut Olson dan Dover, harapan pelanggan adalah pelanggan menyakini nilai/manfaat jasa sebelum menggunakan atau membeli suatu produk diman produk tersebut dijadikan standar atau acuan dalam menilai kinerja produk yang digunakan. Walaupun demikian dalam berbagai hal masih ada berbagai hal yang belum dapat dicapai kesepakatannya, seperti standar harapan yang detail/ spesifik, jumlah standar yang digunakan, ataupun sumber harapan.

Pemasaran didalam bank syariah harus dimanfaatkan dengan baik sehingga mendatangkan kemaslahatan di bagi ummat/kehidupan. Implementasi dari pemsaran ini harus mampu menghadirkan keadilan bagi sosial. Gagasan menghadirkan agama didalam pemasaran ini perlu untuk dilakukan pertimbangan karena apa bila mengalami kegagalan dapat menciptakan keraguan menurut Asnawi (2017).

Konsep pemasaran memberikan penekanan akan pentingnya kepuasan pelanggan dalam menopang keberhasilan perusahaan untuk mencapai tujuannya secara mudah, tingkat kepuasan setiap pelanggan akan produk tertentu adalah nilai dari perbandingan yang dilakukan oleh pelanggan tersebut atas manfaat-manfaat yang diterima atau dipersepsikan (perceived) setelah nasabah menggunakan atau mengkonsumsi jsas dan level manfaat yang diharapkan (expected) oleh nasabah sebelum pembelian. Jika persepsi memiliki nilai sama dan lebih besar dari harapan setelah diperbandingkan, maka nasbah akan puas dan sangat puas. Sebaliknya jika harapan nasabah atau ekspektasi tidak dapat dipenuhi, maka nasabah meraskan tidak puas atau ketidakpuasan. 
Perasaaan kepuasan yang didapat oleh nasabah berulang kali maka dapat menaikkan level kepuasaan secara penuh dan akan memudahkan nasabah dalam membangun ekspektasi yang pasti dimasa yang akan datang. Sehingga kepuasan pelanggan dapat memberikan nilai bagi bank yaitu nasabah yang setia.

Banyak penelitian serta akademisi telah menyadari kebutuhan dalam membangun pengukuran valid dari kualitas pelayanan dalam memberikan pertumbuhan pada jasa beberapa dekade terakhir ini, tapi bagaimanapun pengukuran kualitas pelayanan yang sangat menguntungkan berkat kerja Parasurahamn, Zeithaml, dan Berry yang membangun sebuah model dan pendekatan yang dapat diukur dinamakan SERVQUAL atau kualitas pelayanan (Parasurahman 1985,1988,1990,1992,1993,1994, dan Zeitham 1990). Kualitas pelayanan sebagai sebuah srategi penting dalam meraih sukses dan bertahan pada organisasi-organisasi (Dawkins \& Reichels, 1990), termasuk dalam hal ini adalah bank-bank syariah. Kondisi ini penting bagi bank syariah dalam mengadopsi program kualitas pelayanan dalam mengembangkan dan menyediakan produk serta pelayanan kepada pelanggan mereka agar sukses dalam kompetisi yang keras dari bank nonsyariah atau konvensional dan bank syariah lainnya.

Dalam penelitian ini peneliti menemukan bahwa pelanggan menyadari lima dimensi/faktor yang penting dalam menentukan kualitas pelayanan yaitu: kehandalan atau Reliability, responsif atau Responsiveness, jaminan atau Assurance, empati atau Emphaty, dan wujud atau Tangible. Reliability adalah kemampuan dalam menampilkan jasa yang telah dijanjikan secara konsisten dan tepat. Responsiveness adalah kemampuan bank dalam menyediakan jasa sesuai keinginan nasabah serta membantu pelanggan. Assurance adalah kemampuan karyawan bank terkait dengan pengetahuan, kesopanan serta kemampuan mereka dalam menyakinkan dan memberikan kepercayaan kepada pelanggan. Emphaty adalah perhatian individu yang diberikan kepada pelanggan. Tangible adalah tampilan fisik baik fasilitas-fasilitas, peralatan pe- nampilan personil dan lainnya. Faktor-faktor ini mewakili bagaimana pelanggan mengatur informasi tentang kualitas pelayanan pada pikiran mereka. Berdasarkan penelitian mendalam dan kuantitative, Kelima dimensi ini sangat relevan untuk bank dalam menilai kualitas pelayanan yang diberikan dan mengukur kepuasan pelanggan. Faktor tersebut juga dapat memberikan saran logis untuk pelayanan internal dan terkadang pelanggan akan menggunakan semua dimensi untuk mengukur persepsi dari kualitas pelayanan.

SERVQUAL atau kualitas pelayanan berdasarkan ide bahwa kualitas pelayanan didorong dari perbedaan antara harapan dan tampilan umum dari pelayanan yang diberikan dan menilai penampilan yang aktual dari sebuah kondisi tertentu yang tidak mudah berubah pada suatu komunitas. Kualitas pelayanan telah digambarkan sebagai tingkah laku, berhubungan tetapi tidak sama dengan kepuasan pelanggan dimana hasilnya adalah perbandingan antara pengharapan dengan penampilan.

Muslim dilarang oleh agamanya berhubungan dengan riba, karena itu sistem bank syariah dilarang memberikan bunga kepada mereka yang mendepositokan uangnya ataupun mengumpulkan uang dari meminjam uang.

"Allah memusnahkan riba dan mensyukuri sedekah dan Alah tidak menyukai setiap orang yang tetap dalam kekafiran, dan selalu berbuat dosa" (QS, Al Baqarah (2), 276). Ayat-ayat peringatan terkait dengan riba ini juga dapat ditemui di QS Al Baqarah (2), 275-279. Bank syariah adalah bank yang berdasarkan pada pelarangan bunga, ketidakjelasan (gharar) dan unsur perjudian (maysir) secara besarannya. Berdasarkan atas kondisi diatas maka Othman dan Owen menambahkan satu dimensi lagi pada kualitas pelayanan yaitu compliance. Compliance adalah faktor yang mengukur kemampuan bank dalam memenuhi semua prinsip/hukum Islam serta mengoperasikan bank syariah dibawah prinsip bank dan syariah Islam seperti yang dijelaskan Othman 2001.

Model CARTER ialah alat ukur yang digunakan untuk memperjelas serta mengukur kualitas pelayanan pada bank syariah dan membuat alat 
pengujian yang berkualitas termasuk penerapan hukum Islam dan semua prinsip SERVQUAL lima dimensi sebagaimana dijelaskan di atas. Kedua model tersebut baik CARTER ataupun SERVQUAL memperjelas kepuasan pelanggan sebagai pelayanan yang dapat dilihat, Dimana gap atau perbandingan dari pelayanan yang diharapkan oleh nasabah dengan persepsi dari pelayanan yang diterima nasabah saat itu juga. Sehingga model CARTER membangun sebuah alat ukur bagaimana mengukur kualitas pelayanan pada bank syariah berdasarkan instrumen yang terdiri dari 6 faktor yang dinamakan CARTER (Compliance, Assurance, Reliability, tangibles, Emphaty, Repsonsiveness).

Kepuasan timbul ketika merasakan hal yang diluar dugaan (pelayanan lebih dari yang diperkirakan). Persepsi terhadap kepuasan juga dipengaruhi dengan persepsi timbul dari kelompok atau individu nasabah. Dimensi-dimensi ini diwakili bagaimana pelanggan mengumpulkan informasi mengenai kepuasan pelangan dalam benak mereka.

Kepuasan pelanggan adalah perasaan nasabah atas rasa senang ataupun rasa kecewa yang timbul dari perbandingan antara kesan kinerja atau hasil suatu jasa atas pelayanan yang diberikan dan harapan-harapan yang timbul dari pelanggan. Atas kondisi tersebut dapat difinisikan bahwa kepuasan merupakan fungsi dari hasil kinerja harapan dan harapan yang diinginkan oleh nasabah. Jika kinerja bank syariah dibawah dari harapan nasabah maka nasabah tidak puas, jika output/kinerja dapat memenuhi harapan maka nasabah akan puas dan jika kinerja dari bank syariah melebihi harapan nasabah maka nasabah akan menjadi sangat puas menurut kothler (1997).

Bila dilihat bahwa kepuasan pelanggan yang dirasakan oleh nasabah adalah respon nasabah terhadap ketidaksesuaian/diskonfirmasi yang dirasakan antara harapan sebelumnya (kinerja lainnya) dan kinerja aktual produk yang dirasakan setelah pemakaiannya hal ini yang akan menjadi evaluasi dari nasabah. Kepuasan pelanggan merupakan evaluasi nasabah setelah membeli jasa dari bank syariah, pada kondisi ini alternatif yang lakukan minimal menghasilkan hasil (outcome) sama atau melampaui dari harapan nasabah, sedangkan kondisi nasabah yang mengalami ketidakpuasan muncul karena pelayanan yang dilakukan tidak dapat memenuhi harapan pelanggan (Tjiptono, 1995). Gambar 1 dibawah ini dapat memberikan gambaran secara konseptual akan kepuasan pelanggan. Kepuasaan pelanggan merupakan fungsi dari hasil pelayanan yang diberikan (kinerja) dan harapan. Jika kinerja dari bank syariah dibawah harapan pelanggan maka pelanggan tidak puas, jika pelayanan yang diberikan (kinerja) memenuhi harapan maka pelanggan bank syariah akan merasakan puas dan jika pelayanan yagn diberikan (kinerja) melebihi dari harapan harapan nasabah bank syariah maka nasbah akan merasa puas (Kothler \& Amstrong, 1997).

Kepuasaan pelanggan dipengaruhi oleh ciri khas dan persepsi dari kualitas, kepuasaan pelanggan juga dipengaruhi dengan emosional pelanggan, atribut-atribut dan persepsi equity yang disampaikan oleh Fandy Ciptono. Cirikhasproduk dan layanan terhadap kepuasaan pelangganpada bank syariah sangat dipengaruhi secara signifikan sekali oleh evaluasi nasabah bank syariah terhadap ciri khas atau pelayanan. Emosi yang ditunjukkan oleh nasabah dapat mempengaruhi persepsi kepuasan akan produk dan jasa pada bank syariah, rasa emosi yang tunjukkan oleh nasabah bank syariah ini dapat berubah-ubah sebagai contoh kepuasan sesaat dan kepuasaan hidup. Keluhan pelanggan yang tidak ditangani baik dapat mempengaruhi persepsi dari pelanggan yang dapat mempengaruhi kepuasannya.

Kepuasan ketika merasakan hal yang diluar dugaan (pelayanan lebih atau diluar yang dipikirkan). Nasabah cenderung untuk mencari alasan-alasan akan kepuasaan pelanggan tersebut. Alasan-alasan tersebut bisa jadi dapat mempengaruhi kepuasaaan pelanggan pada bank syariah. Hal ini seperti digambarkan pada gambar dibawah ini. 


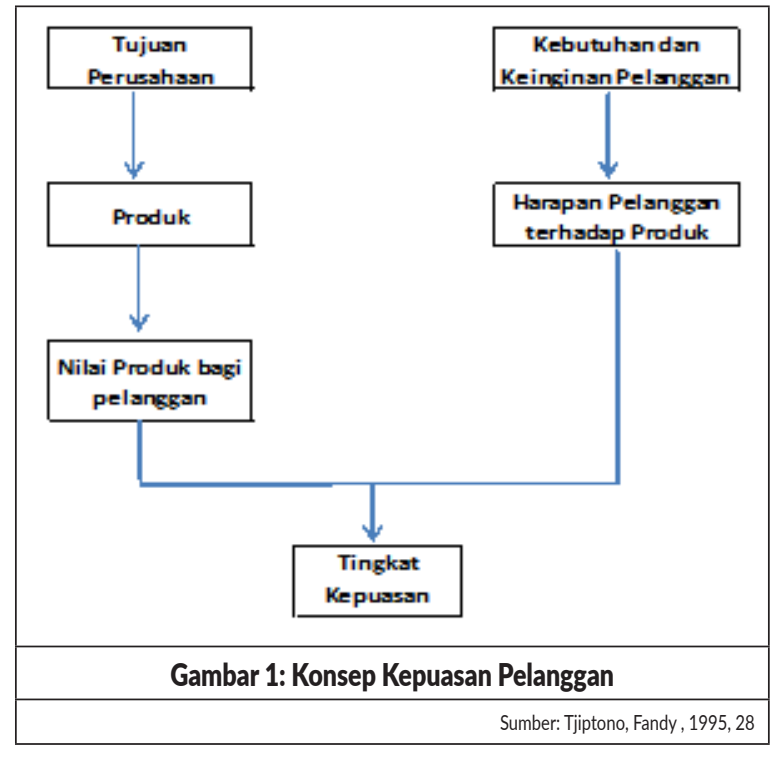

Kepuasan pelanggan seperti kita ketahui adalah perasaan senang atau kecewa nasabah yang muncul dari gap atau perbandingan antara kesan terhadap kinerja ataupun keluaran dari produk/ jasa serta harapan-harapannya.

Banyak pakar yang telah melakukan penelitian terkati dengna kualitas pelayanan dan kepuasaan pelanggan dan diantara pakar-pakar tersebut dalam pemasaran jasa yaitu leonard I Berry, A Parasurahman dan Valerie A Zeithaml 1985, melaksanakan penelitian terkait customer -perceived quality terhadap empat industri jasa yaitu credit securitie, retail banking, maintenance product repair and brokerage. Penelitian yang dilakukan dapat mendefinisikan 5 gap menjadi sebab kegagalan dalam menyampaikan jasa yang akan di ulas sebagai berikut.

Gap pertama adalah antara harapan konsumen dan persepsi manajemen. Pada di dunia nyata manajemen dari perusahaan tidak selalu dapat merasakan dan memahami apa yang menjadi keinginan dari para pelanggan secara tepatnya. Hal ini akan mengakibatkan pihak manajemen tidak dapat memahami bagaimana caranya suatu jasa seharusnya dirancang serta faktor pendukung sekunder apa saja yang konsumen inginkan.

Gap kedua adalah antara persepsi manajemen terhadap harapan konsumen serta kriteria dari kualitas jasa yang diinginkan oleh nasabah. Kondisi ini dapat terjadi pada saat pihak manajemen sudah dapat memahami secara tepat apa yang pelanggan inginkan tetapi pihak manajemen belum menyusun suatu standar kinerja dengan jelas. Kondisi ini dapat timbul oleh tiga faktor yaitu manajemen tidak memiliki komitmen secara total terhadap kualitas jasa, sumber darya yang terbatas, atau karena hanya permintaan yang tinggi atau lebih.

Gap ketiga adalah antara spesifikasi kualitas jasa serta penyampaian jasa. Hal ini dapat disebabkan terjadi seperti karyawan kurang dilatih (belum menguasai tugasnya), melampaui batas beban kerja, standar kinerja yang tidak dapat terpenuhi atau bahkan standar kerja yang telah ditetapkan tidak dapat dipenuhi.

Gap antara penyampaiaan jasa dan komunikasi eksternal. Acapkali harapan pelanggan sudah terpengaruh dengan iklan serta slogan/ pernyataan atau janji yang ditawarkan oleh perusahaan. Risiko yang dihadapi perusahaan adalah jika janji yang ditawarkan ternyata tidak dapat dipenuhi.

Gap antara jasa yang dirasakan dan jasa yang diharapkan (customer gap). Gap ini dapat terjadi jika pelanggan mengevaluasi kinerja/ prestasi perusahaan dengan cara yang berbeda atau bisa juga salah dalam menangkap persepsi dari kualitas jasa tersebut. Dalam hal jasa yang diterima lebih baik dari jasa yang diharapkan oleh pelanggan atau jasa yang diharapkan sama dengan yang diterima, maka perusahaan akan mendapatkan citra dan dampak positif.

Berkaitan dengan hal tersebut maka hal ini menarik bagi peneliti untuk mengkaji dan mendalami lebih lanjut mengenai kualitas pelayanan yang dilakukan di bank syariah "X" dan bagaimana kepuasan nasabah di bank syariah "X tersebut. Hal ini dapat menjadi modal dan pijakan (milestone) untuk pengembangan bank syariah " $\mathrm{X}$ " dalam bersaing di industri perbankan nasional. Peneliti berharap dengan penelitian ini dapat diketahui mengenai kualitas pelayanan yang dilakukan di bank syariah "X" serta kepuasan pelanggan pada nasabah bank "X" yang telah merasakan pelayanan tersebut.

\section{Pembatasan Masalah}

Pada penelitian ini, peneliti mengambil tem- 
pat disalah satu cabang bank syariah di Jakarta, Sehingga output penelitian ini tidak dapat menjadi gambaran secara umum mengenai kualitas pelayanan bank syariah secara keseluruhan. Peneliti mengambil hanya pelayanan produk tabungan saja, sehingga penelitian ini tidak dapat digunakan utnuk menilai pelayanan produk yang lain atau selain tabungan. Penelitian ini hanya melihat 100 orang nasabah di bank syariah "X" yang dijadikan sampel, sehingga hasil yang ditemukan tidak dapat digunakan unnuk menggeneralisasi keseluruhan populasi pengguna tabungan di salah satu cabang bank syariah di daerah Jakarta.

\section{METODE}

\section{Pendekatan, Tipe dan Jenis Penelitian}

Secara teori metode dalam penelitian dapat diartikan sebagai cara ilmiah yang digunakan untuk mengambil data dengan maksud tertentu. Penelitian yang dilakukan ini adalah penelitian deskriptif analitis yang memberikan deskripsi atau gambaran secara sistematis mengenai kejadiaan fakta-fakta ataupun sifat kondisi/situasi dan kejadian, dimana metode ini mengakumulasikan data dasar belaka. Pada penelitian ini menggunakan pendekatan kuntitatif. Penulis mengumpulkan data-data yang diperlukan dari bank syariah " $X$ ", mengolah dan menyajikan data yang terkumpul tersebut dan dianalisa. Penelitian ini dilakukan pada saat tertentu (cross sectional).

\section{Tahapan Penelitian}

Penelitian ini menggunakan teknik/cara mengumpulkan data yaitu pengumpulan data sekunder dan data primer. Data sekunder diambil dari laporan bank syariah "X", bank Indonesia, bukubuku teks, jurnal, literatur-literatur yang memiliki keterkaitan dengan masalah yang dibahas yang biasanya disebut dengan studi kepustakaan (library research). Sedangkan data primer adalah teknik pengamblan datanya melalui observasi yang dilakukan secara langsung dengan mengamati pelayanan yang dilakukan oleh bank syariah"X" disamping dengan menggunakan kuesioner yang dibagikan dan diisi oleh nasabah bank syariah "X".

\section{Populasi}

Penelitian ini mengmbil populasi yaitu seluruh nasabah bank syariah"X" salah satu cabang di Jakarta. Sehubungan dengan keterbatasan dan waktu dan biaya penelitian maka peneliti menggunakan pendekatan sampel dimana pada penelitian ini peneliti menggunakan 2 kali teknik penarikan sampel yaitu menggunakan purposive sampling atau judgemental sampling dan accidental sampling. Pada purposive sampling peneliti memberikan kriteria atau karakteristik nasabah yang akan menjadi sampel penelitian ini. Kriteria tersebut adalah memiliki tabungan di bank syariah "X", usia diatas 17 tahun. Sedangkan untuk accidental sampling pengambilan sampel secara tiba-tiba adalah nasabah yang datang ke kantor bank syariah"X". Kuesioner disebarkan sebanyak 100 responden dan semuanya terisi dengan baik. Pada penelitian ini peneliti juga menanyakan kepada nasabah terkait dengan pemahaman terkait dimensi/faktor compliance yaitu bebas riba, perjudian, ketidakjelasan, investasi yang halal, prinsip keadilan. Nasabah masih perlu dijelaskan sebelum mengisi kuesioner sehingga nasabah dapat mengisi dengan pemahaman yang sama dengan maksud penelitian ini. Penarikan sampel dilakukan selama 2 minggu bertempat di cabang bank syariah"X". Lokasi tersebut terpilih berdasarkan purposive sampling tempat dimana peneliti mengambil responden yang dapat ditemui dan accidental sampling dengan jumlah sample sebanyak 100 responden yang dilakukan secara tiba-tiba. Waktu penelitian dilakukan selama 3 bulan.

Data primer yang telah dikumpulkan melalui kuesioner sebelum dianalisa lebih jauh maka dilakukan beberapa tahapan proses yaitu coding data, pemasukan data, selanjutnya apabila tidak ada kesalahan data siap untuk diolah dan di interprestasikan baru selanjutnya dianalisa.

Peneliti melakukan suatu klasifikasi skor agar dari hasil penelitian yang telah diolah dapat dikategorikan masing-masing menurut persepsi, harapan dan kesenjangan (gap). Agar keseluruhan dapat dilihat mengenai kualitas pelayanan yang dilakukan oleh Bank Syariah "X" dan kepuasan nasabahnya. 
Tehnik analisis dilakukan dengan di beri skor 1-5 yang dinilai secara gradasi yang terdiri dari jawaban sangat berkualitas, berkualitas, cukup berkualitas dan tidak berkualitas serta sangat tidak berkualitas. Jawaban tertinggi adalah sangat berkualitas dengan skor jawaban tertinggi 5 dan jawaban terendahnya adalah sangat tidak berkualitas dengan skor 1, maka untuk mencari lebar kelas adalah 5-1 dan dibagi 5 sehingga diperoleh hasil 0,8. Maka diperoleh skala seperti terlihat di tabel 1 berikut ini:

\begin{tabular}{|c|c|c|}
\hline \multicolumn{3}{|c|}{ Tabel 1. Skor Persepsi } \\
\hline No & SKALA & KELAS \\
\hline 1 & Sangat tidak Berkualitas & $1,00-1,80$ \\
\hline 2 & Tidak Berkualitas & $1,81-2,60$ \\
\hline 3 & Cukup Berkualitas & $2,61-3,40$ \\
\hline 4 & Berkualitas & $3,41-4,20$ \\
\hline 5 & Sangat Berkualitas & $4,21-5,00$ \\
\hline
\end{tabular}

Tingkat kepuasaan nasabah diukur dengan menggunakan gap. Hal ini dilakukan dengan melakukan perbandingan atau pengurangan antara skor persepsi dengan harapan. Hasil dari gap tersebut apabila persepsi lebih besar dari skor harapan maka masuk kategori puas dan apabila skor persepsi lebih kecil dari skor harapan maka masuk kedalam ketegori tidak puas sedangkan bila skor sama maka masuk kategori puas. Hal ini dapat telihat seperti tabel 2 dibawah:

\begin{tabular}{|c|l|c|}
\hline \multicolumn{3}{|c|}{ Tabel 2. Klasifikasi Tingkat Kepuasaan Pelanggan } \\
\hline NO & \multicolumn{1}{|c|}{ SKALA } & KATEGORI \\
\hline 1 & Persepsi $>$ Harapan & Puas \\
\hline 2 & Persepsi = Harapan & Cukup Puas \\
\hline 3 & Persepsi $<$ Harapan & Tidak Puas \\
\hline
\end{tabular}

Sebelum dilakukan analisa, peneliti membuat operasionalisasi konsep yang dijabarkan dari 6 faktor yang dipakai untuk meneliti kualitas pelayanan dan kepuasan pelanggan di bank syariah "X". Operasionalisasi konsep ini penting untuk menangkap persepsi dan keinginan pelanggan serta menilai terkait dengan pelayanan yang dirasakan atau diterima oleh pelanggan. Peneliti menjabarkan 6 faktor CARTER (Compliance, Assurance, Reliability, Tangibles, Emphaty, Repsonsiveness) menjadi 31 variabel yang digunakan untuk menilai persepsi dari pelanggan bank syariah "X" tersebut. Adapun detail dari Operasionalisasi konsep penelitian ini dijelaskan pada tabel 3 dibawah ini:

\begin{tabular}{|c|c|c|c|}
\hline \multicolumn{4}{|c|}{ Tabel 3. Operasionalisasi Konsep } \\
\hline NO & VARIABEL & INDIKATOR & ATRIBUT \\
\hline \multirow{31}{*}{1} & \multirow{31}{*}{$\begin{array}{l}\text { Kualitas } \\
\text { Pelayanan }\end{array}$} & \multirow{5}{*}{ Compliace } & Bebas dari sistem bunga \\
\hline & & & Investasi yang halal \\
\hline & & & Bebas dari perjudian/maysir \\
\hline & & & Bebas dari ketidakjelasan/gharar \\
\hline & & & Bebas dari ketidakadilan \\
\hline & & \multirow{5}{*}{ Assurance } & $\begin{array}{l}\text { Bank pertama yang menerapkan prinsip } \\
\text { syariah }\end{array}$ \\
\hline & & & Karyawan yang terpercaya \\
\hline & & & Berakhlak baik dan bersahabat \\
\hline & & & Perasaan aman dalam bertransaksi \\
\hline & & & Karyawan yang berpengalaman \\
\hline & & \multirow{5}{*}{ Reliability } & Jasa dilakukan dengan benar dari awal \\
\hline & & & $\begin{array}{l}\text { Bersikap simpatik dan sanggup } \\
\text { menenangkan nasabah }\end{array}$ \\
\hline & & & $\begin{array}{l}\text { Jasa disampaikan sesuai waktu yang } \\
\text { dijanjikan }\end{array}$ \\
\hline & & & Sistem yang akurat dan bebas kesalahan \\
\hline & & & Pelayanan yang cepat \\
\hline & & \multirow{5}{*}{ Tangible } & Fasilitas fisik yang berdaya tarik \\
\hline & & & Peralatan yang mutakhir \\
\hline & & & Karyawan yang berpenampilan rapi \\
\hline & & & Tempat parkir \\
\hline & & & Interior yang nyaman \\
\hline & & \multirow{6}{*}{ Emphaty } & Lokasi bank (mudah dicapai) \\
\hline & & & Perhatian bank syariah secara individu \\
\hline & & & $\begin{array}{l}\text { Waktu beroperasi yang sesuai bagi } \\
\text { nasabah }\end{array}$ \\
\hline & & & Perhatian secara personal dari karyawan \\
\hline & & & Memahami kebutuhan spesifik nasabah \\
\hline & & & $\begin{array}{l}\text { Memberikan masukan dalam hal } \\
\text { keuangan }\end{array}$ \\
\hline & & \multirow{5}{*}{ Repsonsiveness } & Layanan yang sangat cepat \\
\hline & & & $\begin{array}{l}\text { Penyampaian jasa diinformasikan dengan } \\
\text { jelas }\end{array}$ \\
\hline & & & $\begin{array}{l}\text { Menanggapi permintaan nasabah dengan } \\
\text { cepat }\end{array}$ \\
\hline & & & Ketepatan dalam jam buka pelayanan \\
\hline & & & Mudah dalam mengakses informasi \\
\hline \multirow{3}{*}{2} & \multirow{3}{*}{$\begin{array}{l}\text { Kepuasan } \\
\text { Pelanggan }\end{array}$} & \multicolumn{2}{|c|}{ Persepsi > Harapan Puas } \\
\hline & & \multicolumn{2}{|c|}{ Persepsi $=$ Harapan Cukup Puas } \\
\hline & & \multicolumn{2}{|c|}{ Persepsi < Harapan Tidak Puas } \\
\hline
\end{tabular}

\section{HASIL dan PEMBAHASAN}

Hasil

Pada penelitian ini didapatkan profile responden laki-laki sebanyak 48 dan perempuan sebanyak 52 dengan presentasi $48 \%$ dan $52 \%$ seperti pada tertera pada tabel 4 di bawah ini. 


\begin{tabular}{c|l|c|c|}
\hline \multicolumn{4}{|c}{ Tabel 4. Jenis Kelamin } \\
\hline NO & JENIS KELAMIN & JUMLAH & PERSEN \\
\hline 1 & Laki-laki & 48 & $48 \%$ \\
\hline 2 & Perempuan & 52 & $52 \%$ \\
\hline \multicolumn{2}{|c|}{ Total } & 100 & $100 \%$ \\
\hline
\end{tabular}

Di dalam penelitian ini responden memiliki usia yang didominasi oleh usia 17 s.d. 25 tahun dengan jumlah responden sebanyak 34.usia, lebih dari 25 s.d. 30 tahun berjumlah 26 responden, selanjutnya umur lebih 30 s.d. 35 tahun sebanyak 14 responden, usia diatas 35 tahun s.d. 40 tahun sebanyak 10 responden, usia lebih dari 40 s.d. 45 tahun berjumlah 8 responden serta lebih dari 45 tahun berjumlah 8 responden. Data diatas memperlihatkan usia responden yang menyimpan uang di bank syariah masuk kategori produktif dengan usia dibawah 40 tahun. Tabel data usia responden dapat dilihat pada tabel 5 berikut:

\begin{tabular}{|c|l|c|c|}
\hline \multicolumn{4}{|c|}{ Tabel 5. Usia } \\
\hline NO & \multicolumn{1}{|c|}{ USIA } & JUMLAH & PERSEN \\
\hline 1 & $17-25$ tahun & 34 & $34 \%$ \\
\hline 2 & $>25-30$ tahun & 26 & $26 \%$ \\
\hline 3 & $>30-35$ tahun & 14 & $14 \%$ \\
\hline 4 & $>35-40$ tahun & 10 & $10 \%$ \\
\hline 5 & $>40-45$ tahun & 8 & $8 \%$ \\
\hline 6 & $>45$ tahun & 8 & $8 \%$ \\
\hline \multicolumn{2}{|c|}{ Total } & 100 & $100 \%$ \\
\hline
\end{tabular}

Pada tingkat pendidikan responden lebih banyak di tingakt Strata 1 (S1) sebanyak 36 responden, tingkat pendidikan Diploma sebanyak 31 responden dan SLTP \& SLTAsebanyak 30 orang. Responden dengna tingkat pendidikan SD berjumlah 1 nasabah serta jenjang Master dengan 2 responden. Data ini digambarkan pada grafik 6 dibawah ini.

\begin{tabular}{|c|l|c|c|}
\hline \multicolumn{4}{|c|}{ Tabel 6. Tingkat Pendidikan } \\
\hline NO & JENJANG PENDIDIKAN & JUMLAH & PERSEN \\
\hline 1 & SD & 1 & $1 \%$ \\
\hline 2 & SLTP \& SLTA & 30 & $30 \%$ \\
\hline 3 & Diploma & 31 & $31 \%$ \\
\hline 4 & Sarjana (S1) & 36 & $36 \%$ \\
\hline 5 & Master (S2) & 2 & $2 \%$ \\
\hline \multicolumn{2}{|c|}{ Total } & 100 & $100 \%$ \\
\hline
\end{tabular}

Penelitian ini banyak yang menajwab dari pegawai swasta sebanyak 25 repsonden, selanjutnya mahaiswa/pelajar dan PNS menempati urutan kedua sebanyak 16 responden sisanya dosen dan pengusaha/wiraswasta sejumlah 13 responden. Ibu tidak bekerja atau rumah tangga sebanyak 11 responden serta pekerjaan lainnya sejumlah 6 reponden. Data mengenai pekerjaan ini digambarkan pada pada tabel 7 dibawah ini.

\begin{tabular}{|c|l|c|c|}
\hline \multicolumn{4}{|c}{ Tabel 7. Pekerjaan } \\
\hline NO & JENJANG PENDIDIKAN & JUMLAH & PERSEN \\
\hline 1 & Pelajar/Mahasiswa & 16 & $16 \%$ \\
\hline 2 & Guru/Dosen & 13 & $13 \%$ \\
\hline 3 & Wlraswasta & 13 & $13 \%$ \\
\hline 4 & lbu Rumah Tangga & 11 & $11 \%$ \\
\hline 5 & PNS & 16 & $16 \%$ \\
\hline 6 & Pegawai Swasta & 25 & $25 \%$ \\
\hline 7 & lainnya & 6 & $6 \%$ \\
\hline & Total & 100 & $100 \%$ \\
\hline
\end{tabular}

Seluruh responden pada penelitian ini adalah pemilik tabungan dibank syariah " $\mathrm{X}$ " yang tergambarkan di dalam tabel 8 dibawah ini.

\begin{tabular}{|c|c|c|c|}
\hline \multicolumn{4}{|c|}{ Tabel 8. Kepemilikan Tabungan Umat } \\
\hline NO & KEPEMILIKAN TABUNGAN & JUMLAH & PERSEN \\
\hline 1 & Ya & 100 & $100 \%$ \\
\hline 2 & Tidak & 0 & $0 \%$ \\
\hline & Total & 100 & $100 \%$ \\
\hline
\end{tabular}

Pada tabel 9 dibawah ini terlihat bahwa 85 responden belum memiliki produk selain tabungan dan hanya 15 responden yang sudah memiliki produk lain. Tabel terkait dengan kepemilikan produk selain tabungan digambarkan dibawah ini.

\begin{tabular}{|c|c|c|c|}
\hline \multicolumn{4}{|c|}{ Tabel 9. Kepemilikan Produk Selain Tabungan } \\
\hline NO & KEPEMILIKAN PRODUK LAIN & JUMLAH & PERSEN \\
\hline 1 & $\mathrm{Ya}$ & 15 & $15 \%$ \\
\hline 2 & Tidak & 85 & $85 \%$ \\
\hline & Total & 100 & $100 \%$ \\
\hline
\end{tabular}

Sebanyak 44 responden telah memiliki tabungan antara 1 s.d. 4 tahun. responden yang memiliki tabungan dibawah 1 tahun sebanyak 28 responden sedangkan 13 reponden memiiki tabungan antara 4 s.d. 7 tahun dan 15 responden memiliki tabungan diatas 7 tahun. Gambaran responden pada penelitian ini terkait dengan kepemilikan produk selain tabungan dapat dilihat pada tabel 10 dibawah ini. 


\begin{tabular}{|c|c|c|c|}
\hline \multicolumn{4}{|c|}{ Tabel 10. Waktu Kepemilikan Tabungan } \\
\hline No & WAKTU KEPEMILIKAN & JUMLAH & PERSEN \\
\hline 1 & $<1$ tahun & 28 & $28 \%$ \\
\hline 2 & $>1-4$ tahun & 44 & $44 \%$ \\
\hline 3 & $>4-7$ tahun & 13 & $13 \%$ \\
\hline 4 & $>7-10$ tahun & 15 & $15 \%$ \\
\hline & Total & 100 & $100 \%$ \\
\hline
\end{tabular}

Berdasarkan hasil Analisa yang dilakukan oleh penulis setelah mengumpulkan data, maka langkah yang diambil oleh peneliti pada penelitian ini selanjutnya yaitu cara menganalisa data yang telah dikumpulkan. Analisa data ini memiliki tujuan untuk mengkategorikan dan menginterprestasikan data-data kuantitatif yang telah di peroleh. Selanjutnya kita akan melihat hasil dari persepsi nasabah terkait degan pelayanan perbankan yang mereka rasakan di bank syariah "X".

Pada faktor compliance, pemenuhan akan prinsip syariah terlihat bahwa skor tertingi untuk kualitas pelayanan dinilai pelanggan dari hal kemampuan bank syariah dalam melakukan investasi secara halal dengan nilai sejumlah 4,47 dengan kategori sangat berkualitas. Sedangkan skor terendah terdapat pada atribut bebas dari ketidakadilan dengan jumlah nilai sebesar 4,07 dimana masuk range kategori berkualitas. Atribut bebas dari system bunga memiliki skor 4,28 dengan kategori sangat berkualitas, atribut bebas dari praktek maysir atau perjudian memiliki skor 4,42 dengan kategori sangat berkualitas dan atribut bebas dari praktek ketidak jelasan mendapatkan skor sebesar 4,12 dengan kategori berkualitas.

Faktor Assurance, keyakinan atau kepercayaan pelanggan bank syariah " $\mathrm{X}$ " memiliki skor tertinggi yaitu bank syariah pertama dan ternama dengan skor 4,3 dimana masuk kedalam kategori sangat berkualitas. Skor terendah adalah sebesar 3,36 terkait dengan pengalaman karyawan bank syariah " $X$ " yang masuk kategori berkualitas. Atribut bank terpercaya mendapatkan skor sebesar 3,39 dengan katergori berkualitas. Atribut aman dalam bertransaksi mendapatkan skor 4,15 dengan kategori berkualitas dan atribut berakhlak baik dan bersahabat mendapatkan skor 4,12 dengan kategori berkualitas.
Faktor Reliability, kehandalan bank syariah dimana skor tertinggi ada pada atribut penyampaian jasa sesuai dengan waktu yang dijanjikan mendapatkan skor sejumlah 3,79 dengan kategori berkualitas. Skor terendah yaitu pada akurat dan bebas kesalahan dengan nilai sebesar 3,34 dengan kategori cukup berkualitas. Atribut jasa di lakukan dengan benar dari awal mendapatkan skor sebesar 3,85 dengan kategori berkualitas. Atribut Karyawan memiliki simpati dan dapat menenangkan nasabah memiliki skor 3,88 dengan kategori berkualitas. Atribut memberikan pelayanan yang cepat mendapatkan skor sebesar 3,92 dan masuk kategori berkualitas.

Faktor Tangible atau tampilan fasilitas-fasilitas, peralatan, penampilan personil dimana skor tertingginya ada pada atribut Karyawan berpenampilan rapih dengan skor 4,1 masuk kategori berkualitas. Skor terendah sebesar 3,48 dengan atribut peralatan yang mutakhir masuk kedalam kategori berkualitas. Atribut desain gedung menarik dan mudah dikenali (unik) mendapatkan skor sebesar3,74 yang masuk kategori berkualitas. Atribut tempat parkir yang luas mendapatkan skor sebesar 3,68 dengan kategori berkualitas. Atribut nasabah nyaman memiliki skor sebesar 3,9 dengan kategori berkualitas.

Faktor Empathy, perhatian individu yang diberikan kepada pelanggan dengan skor tertinggi pada atribut jam operasional sesuai bagi nasabah dengan nilai 3,95 dengan kategori berkualitas. Sedangkan skor terendah pada atribut memahami kebutuhan spesifik nasabah sebesar 3,52 dengan kategori berkualitas. Atirbut lokasi mudah dicapai mendapatkan skor 3,79 dengan kategori berkualitas. Atribut mengakomodir saran yang diberikan nasabah mendapatkan skor sebesar 3,61 dengan kategori berkualitas. Atribut perhatian personal kepada nasabah mendapatkan skor 3,74 dengan kategori berkualitas.

Faktor responsiveness, kemauan untuk membantu nasabah dan memenuhi keinginan nasabah dengan skor tertinggi 3,94 adalah atribut memberikan informasi yang jelas dan masuk kategori berkualitas. Atribut terendah dengan skor kemudahan mengakses informasi rekening dengan skor 3,71 dengan kategori berkualitas. 


\begin{tabular}{|c|c|c|c|c|c|c|}
\hline \multicolumn{7}{|c|}{ Tabel 11: Penilaian nasabah ba nk syariah " $X$ " (persepsi dan harapan) } \\
\hline \multirow{2}{*}{ No } & \multirow{2}{*}{ Atribut } & \multirow{2}{*}{ Indikator } & \multicolumn{2}{|c|}{ Kualitas Pelayaman } & \multicolumn{2}{|c|}{ Kepuasan Pelanggan } \\
\hline & & & Sloor & kategori & Gap & Kategori \\
\hline 1 & Bebas dari sistem bunga & \multirow{5}{*}{ Compliance } & 4,28 & S angat Berkualitas & $-0,34$ & Tidak Puas \\
\hline 2 & Investasi yang halal & & 4,47 & S angat Berkualitas & $-0,23$ & Tidak Puas \\
\hline 3 & Bebas dari perjudianmaysir & & 4,42 & S angat Berkualitas & $-0,3$ & Tidak Puas \\
\hline 4 & Bebas dari ketidakjelasan/gharar & & 4,12 & Berlaualitas & $-0,52$ & Tidak Puas \\
\hline 5 & Bebas dati ketidakadilan & & 4,07 & Berkualitas & $-0,46$ & Tidak Puas \\
\hline 6 & Bank pertama yang menerapkan prinsip syariah & \multirow{5}{*}{ Assurance } & 4,3 & S angat Berkualitas & $-0,16$ & Tidak Puas \\
\hline 7 & Karyawan yang terpercaya & & 3,95 & Berkualitas & $-0,53$ & Tidak Puas \\
\hline 8 & Berakhlak b aik an bersahabat & & 4,12 & Berlaualitas & $-0,5$ & Tidak Puas \\
\hline 9 & Perasaan aman dalam bertransaksi & & 4,15 & Berlaualitas & $-0,46$ & Tidak Puas \\
\hline 10 & Karyawan yang berpengalannan & & 3,63 & Berlaualitas & $-0,77$ & Tidak Puas \\
\hline 11 & Jasa dilakukandengan benar dari aw al & \multirow{5}{*}{ Reliability } & 3,65 & Berlaualitas & $-0,57$ & Tidak Puas \\
\hline 12 & Bers ilap simpatik dan sanggup menenangkan nasab ah & & 3,88 & Berlaualitas & $-0,58$ & Tidak Puas \\
\hline 13 & Jasa disampaikan sesuaiw aktu yang dijanjikan & & 3,97 & Berkualitas & $-0,46$ & Tidak Puas \\
\hline 14 & Sistem yarg akurat dan bebas kesalahan & & 3,34 & Cukup Berkualitas & $-1,01$ & Tidak Puas \\
\hline 15 & Pelayananyang cepat & & 3,92 & Berkualitas & $-0,59$ & Tidak Puas \\
\hline 16 & Fasilitas fisik yang berdaya tarik & \multirow{5}{*}{ Tangible } & 3,75 & Berkualitas & $-0,58$ & Tidak Puas \\
\hline 17 & Peralatan yang mutakhir & & 3,48 & Berkualitas & $-0,91$ & Tidak Puas \\
\hline 18 & Karyawan yang berpenampilan rapi & & 4,1 & Berkualitas & $-0,45$ & Tidak Puas \\
\hline & Tempat Parkir & & 3,68 & Berkualitas & $-0,72$ & Tidak Puas \\
\hline 20 & Interior yang nyaman & & 3,9 & Berlaualitas & $-0,58$ & Tidak Puas \\
\hline & Lolasib ank (mudah dicapai) & \multirow{5}{*}{ Emphaty } & 3,79 & Berlaualitas & $-0,81$ & Tidak Puas \\
\hline & Perhatian bark syariah secara individu & & 3,61 & Berlaualitas & $-0,8$ & Tidak Puas \\
\hline 23 & Waktu beroperasi yang cocolonyaman bagi nas abah & & 3,95 & Berloualitas & $-0,47$ & Tidak Puas \\
\hline 24 & Perhatian secara personal dari laryawan & & 3,74 & Berkualitas & $-0,66$ & Tidak Puas \\
\hline & memahami kebutuhan spesifik nasab ah & & 3,52 & Berlaualitas & $-0,83$ & Tidak Puas \\
\hline 26 & Layananyang sangat cepat & \multirow{5}{*}{ Responsiveness } & 3,94 & Berlaualitas & $-0,55$ & Tidak Puas \\
\hline & Penyampaian jasa dïnformasikan dengna jelas & & 3,98 & Berlavalitas & $-0,56$ & Tidak Puas \\
\hline & menaggapi permintaan nasabah dergan cepat & & 3,8 & Berkualitas & $-0,66$ & Tidak Puas \\
\hline & Ketepatan dalam jam buka pelayaran & & 3,78 & Berlaualitas & $-0,76$ & Tidak Puas \\
\hline 30 & Mvdah dalam mengakses informasi & & 3,71 & Berkualitas & $-0,83$ & Tidak Puas \\
\hline
\end{tabular}

Atribut pelayanan cepat dan efisien memiliki skor sebesar 3,94 dengan kategori berkualitas. Atribut menanggapi permintaan nasabah dengan cepat memiliki skor 3,8 dengan kategori berkualitas. Atribut membuka pelayanan on time/ tepat waktu dengan skor 3,78 masuk kategori berkualitas. Detail dari hasil persepsi nasabah terkait dengan kulitas pelayanan yang diterima digambarkan seperti tabel 11 diatas.

Selain kualitas pelayanan yang diterima oleh nasabah kita dapat melihat kepuasan pelanggan pada bank syariah"X" yang tertera pada tabel 4 diatas dengan penjabaran sebagai berikut:

Pada faktor compliance nilai gap tertinggi pada atribut praktek ketidakjelasan/gharar dengan skor sebesar -0,52 dengan kategori tidak puas. Sedangkan gap terendah pada atribut dana diinvestasikan pada investasi yang halal dengan skor sebesar -0,23 masuk kategori tidak puas. Atribut bebas dari sistem bunga mendapatkan skor -0,34 kategori tidak puas. Atribut bebas dari perjudian memiliki skor -0,3 dengan kategori tidak puas. Sedangkan atribut bebas dari praktek ketidakadilan memiliki skor sebanyak -0,48 dengan kategori tidak puas.

Faktor assurance nilai gap tertinggi pada atribut Karyawan bank syariah terpercaya dengan nilai -0,53 dengan kategori tidak puas. Gap terendah ada pada atribut bank pertama dan ternama dengan nilai - 0,18 masuk kedalam kategori tidak puas. Atribut Karyawan berakhlak baik dan bersahabat memiliki nilai gap sebesar $-0,5$ dengan kategori tidak puas. Atribut aman bertransaksi memiliki nilai gap sebesar -0,46 dan masuk kategori tidak puas. Sedangkan atribut Karyawan berpengalaman memiliki nilai gap sebesar -0,77 dengan kategori tidak puas.

Faktor realibiity memiliki nilai gap tertinggi dengan pada atribut sistem akurat dan bebas kesalahan dengan nilai -1,01 dengan kategori tidak 
puas. Sedangkan nilai gap terendah ada pada atribut penyampaian jasa tepat waktu dengan nilai -0,46 masuk kategori tidak puas. Atribut jasa dilakukan dengan benar dari awal memiliki nilai gap -0,57 dengan kategori tidak puas. Atribut Karyawan bersikap simpati dan sanggup menenangkan nasabah memiliki nilai gap -0,58 dengan kategori tidak puas. Atribut bank syariah "X" dalam melakukan/memberikan pelayanan yang cepat dengan skor gap sebesar -0,59 dengan kategori tidak berkualias.

Faktor tangible memiliki nilai gap tertinggi pada atribut peralatan mutakhir dengan nilai $-0,91$ dengan kategori tidak puas sedangkan atribut Karyawan berpenampilan rapi memiliki nilai gap terendah sebesar -0,45 masuk kedalam kategori tidak puas. Atribut desain gedung menarik dan mudah dikenali dengan nilai gap sebesar -0,58 dengan kategori tidak puas. Atribut parkir yang tersedia luas dengan nilai gap skor sebesar - 0,72 dengan kategori tidak puas. Atribut interior membuat nasabah nyaman memiliki nilai gap sebesar -0,58 dengan kategori tidak puas.

Faktor emphaty memiliki nilai gap tertinggi pada atribut Karyawan memahami kebutuhan spesifik Karyawan dengan nilai gap sebesar -0,83 dengan kategori tidak puas. Sedangkan skor gap terendah dimiliki oleh atribut jam operasional cocok/sesuai dengna nasabah dengan nilai $-0,47$ dan masuk kategori tidak puas. Atribut lokasi mudah dicapai dengan nilai gap sebesar - 0,8 masuk kategori tidak puas. Atribut perhatian terhadap nasabah/mengakomodir saran dari nasabah memiliki nilai gap sebesar $-0,8$ dengan kategori tidak puas. Atribut memberikan perhatian personal ke nasabah dengan nilai gap - 0,66 dengan kategori tidak puas.

Faktor responsiveness memiliki nilai gap tertinggi pada atribut kemudah akses informasi rekening dengan nilai gap -0,83 masuk kategori tidak puas. Sedangkan nilai gap terendah pada atribut pelayanan counter cepat dan effisien dengan nilai gap sebesar -0,55 dengan kategori tidak puas. Atribut Karyawan memberikan informasi dengan jelas memiliki nilai gap sebesar -0,56 dengan kategori tidak puas. Atribut Karyawan menaggapi permintaan nasabah dengan cepat dengan nilai gap -0,66 masuk kedalam ketegori tidak puas. Atribut pealayanan on time dengan nilai gap -0,76 masuk kategori tidak puas.

\section{Pembahasan}

Pada tabel yang ditampilkan diatas terlihat rata-rata pelayanan yang diberikan bank syariah 'X' berkualitas dan bahkan ada yang sangat berkualitas untuk atribut 1, 2, 3, 6. Hal ini penting untuk dipertahankan oleh bank syariah "X". Sedangkan untuk yang masuk kategori berkualitas masih perlu untuk di tingkatkan lagi agar menjadi sangat berkualitas. Pada tabel di atas juga ditemukan bahwa skor terendah adalah indikator untuk sistem bank syariah ' $\mathrm{X}$ ' no.14 yaitu sistem yang akurat dan bebas dari kesalahan. Dengan skor 3,34 yang masuk kategori cukup berkualitas. Skor tersebut menandakan penilaian nasabah bank syariah ' $\mathrm{X}$ ' mengenai hal tersebut dirasakan kurang diperhatikan pada bank syariah"X" sehingga kedepannya bank syariah ' $\mathrm{X}$ " harus meningkatkan kualitas sistem sehingga bebas dari kesalahan dan akurat.

Selain hal diatas mengenai kualitas pelayanan yang dilakukan oleh bank syariah " $\mathrm{X}$, terlihat juga bahwa kepuasan pelanggan terlihat semua atribut masuk kedalam kategori tidak puas. Hal ini menandakan bahwa walaupun bank syariah ' $\mathrm{X}$ ' telah memberikan pelayanan yang berkualitas namun nasabah bank syariah "X" masih merasakan ketidakpuasan. Sehingga kedepannya bank syariah "X" agar lebih meningkatkan kualitas pelayanannya agar dapat memuaskan nasabahnya. Hal ini penting dalam rangka berkompetisi dengan bank syariah lainnya dan juga dengan bank konvensional. Kedepannya bank syariah " $\mathrm{X}$ " tidak hanya meraih pasar emosional saja tetapi dapat pula bersaing di pasar yang rasional.

Tabel 5. Skor Persepsi, Harapan, Gap Serta Tingkat Kepuasaan Untuk Setiap Dimensi

\begin{tabular}{|c|l|c|c|c|}
\hline \multirow{2}{*}{ NO } & \multirow{2}{*}{ DIMENSI } & \multicolumn{3}{|c|}{ SKOR } \\
\cline { 3 - 5 } & & PERSEPSI & HARAPAN & GAP \\
\hline 1 & Compliance & 4,27 & 4,65 & $-0,38$ \\
\hline 2 & Assurance & 4,11 & 4,52 & $-0,41$ \\
\hline 3 & Reliability & 3,79 & 4,43 & $-0,64$ \\
\hline 4 & Tangibles & 3,78 & 4,44 & $-0,65$ \\
\hline 5 & Emphaty & 3,8 & 4,51 & $-0,64$ \\
\hline 6 & Repsonsiveness & 3,84 & 4,51 & $-0,67$ \\
\hline
\end{tabular}


Pada tabel diatas terlihat bahwa dimensi compliance memiliki gap sebesar -0,38. Secara umum nasabah bank syariah "X" merasa tidak puas dengan penerapan prinsip syariah yang diterapkan oleh bank syariah " $\mathrm{X}$ " walaupun bank syariah "X" sudah memberikan pelayanan dengan tingkat yang sangat berkualitas, untuk itu hal ini perlu dilakukan perbaikan kedepannya.

Dimensi assurance memiliki gap sebesar -0,41 dimana masuk kedalam kategori tidak puas. Walaupun Bank syariah " $\mathrm{X}$ " telah melakukan pelayanan berkualitas yang tercermin dari nilai sebesar 4,11. Kedepannya, gap ini menjadi salah satu perhatian khusus bagi bank syariah ' $\mathrm{X}$ ' untuk dapat meningkatkan pengetahuan, kesopanan serta kemampuan Karyawan yang dapat memberikan keyakinan dan kepercayaan kepada nasabah.

Kemampuan bank syariah "X" dalam memberikan penampilan jasa yang dijanjikan secara konsisten dan akurat (reliability) dirasakan oleh nasabah masuk dalam kategori berkualitas dengan skor 3,79. Skor untuk kepuasaan nasabah didapat sebesar -0,64 dimana yang berarti bahwa pelanggan merasa tidak puas dengan pelayanan telah dilakukan oleh bank syariah "X". sehingga kemampuan Karyawan untuk dimensi ini perlu untuk ditingkatkan.

Tangible atau tampilan fisik baik fasilitas, peralatan dan penampilan personil yang dapat dilihat oleh nasabah. Skor untuk kualitas yang telah di lakukan oleh bank syariah " $\mathrm{X}$ " adalah sebesar 3,78 . Namun demikian usaha yang dilakukan perlu untuk ditingkatkan lagi karena masih adanya skor gap kepuasaan nasabah sebesar-0,65 yang masuk kategori tidak puas.

Faktor emphaty yang diberikan oleh Karyawan bank syariah 'X" perlu untuk ditingkatkan karena nasabah masih merasakan tidak puas dengan skor sebesar - 0.67 walaupun bila kita lihat emphaty yang dilakukan sudah bagus atau berkualitas. Perlu dilakukan training agar para front liner di bank syariah " $\mathrm{X}$ " dapat meningkatkan kemampuannya.

Bank syariah "X" mendapatkan nilai skor sebesar 3,84 yang masuk kategori berkualitas dan skor gap sebesar -0,67 dimana masuk kategori tidak puas. Pelanggan menilai bahwa pelayanan yang diberikan sudah berkualitas namun belum dapat memuaskan pelanggan. Sehingga bank syariah " $X$ " perlu untuk meningkatkan pelayanannya terkait dengan kemampuannya dalam merespon nasabah dan menyediakan jasa sesuai keinginan pelanggan.

Berdasarkan tabel diatas kita bisa melihat bahwa walaupun pelayanan yang diberikan oleh bank syariah "X" sudah berkualitas nasabah bank syariah " $\mathrm{X}$ " masih belum puas dengan pelayanan yang diterima. Hal ini terlihat dari keseluruhan indikator masih belum terpuaskan. Kedepannya bank syariah " $X$ " perlu meningkatkan kualitas pelayanannya sehingga dapat memuaskan nasabah. Hal ini penting dalam rangka berkompetisi dengan bank konvensional dan bank syariah lainnya. Sehingga kedepannya bank syariah tidak hanya meraih pasar emosional saja tetapi dapat pula bersaing dipasar yang rasional.

\section{SIMPULAN}

Secara umum bahwa pelayanan yang dilakukan oleh bank syariah "X" terhadap nasabahnya yang dilihat dengan model CARTER berkualitas dan untuk dimensi compliance sangat berkualitas. Kondisi ini ditandai dengan nilai sebesar 3,92 dimana masuk pelayanan yang berkualitas.

Nasabah bank syariah "X" merasakan belum terpuaskan dengan pelayanan yang telah dilakukan oleh bank syariah " $\mathrm{X}$ " hal ini terlihat dari skor total sebesar -0,57 dimana masuk kategori tidak puas. Dimensi yang perlu di perhatikan lebih atau prioritas adalah dimensi responsiveness, tangible, emphaty, dan reliability dimana mendapatkan skor rendah.

Pada penelitian ini terlihat indikasi bahwa nasabah bank syariah " $\mathrm{X}$ " adalah nasabah yang emosional (emotional market) yaitu nasabah yang masih berpikir bahwa mereka menyimpan uang di bank syariah " $X$ " disebabkan sesuai dengan syariah islam dalam hal ini factor kehalalalnya bukan keuntungan yang ditimbulkan/diberikan oleh bank syariah"X" 


\section{DAFTAR PUSTAKA}

Asnawi, N., \& Fanani, A. M. (2017). Pemasaran Syariah Teori, Filosofi \& Isu-Isu Kontemporer.

Angur, M., \& Nataraharja, R., Jahera. (1999). SQ in Banking Industry: an Asset in Developing Economy: International Jurnal of Banking Marketing.

Badudu, R. (2015). Service Excellence. Jakarta: Kompas.

Blanchard, R., \& Galloway R. (1994). Quality in Retail Banking. International Journal of Service Industry Management.

Buttle, F. (1996) SERVQual: Review, Critique, Research Agenda. Eropean Journal of Marketing.

Alfred, T., \& Adams, H. (2010). Service Quality at Banks and Credit Unions What Do Their Costumers Says, Managing Service Quality.

Antonio, \& Muhammad, S. (2000). Bank Syariah: Suatu Pengenalan Umum. Jakarta. Tazkia Institute.

Griffin, J. (1995). Customer Loyalty. How to Keep It. Lexington Books.

Karim, A. (2011). Ekonomi Islam Suatu Kajian Kontemporer. Jakarta. Gema Insani Press.

Kertajaya, H., \& Setiawan, I. (2014). Wow Marketing. Jakarta: Gramedia.

Kothler, P. (1991). Marketing Management: Analisys, Planning and Control. Prenctice Hall. Eaglewood Cliff.

Kothler, P., \& Gary, A. (1997). Dasar-Dasar Pemasaran. Jakarta: Prenticehill.

Lupiyoadi, R. (2001). Manajemen Pemasaran Jasa. Jakarta: Salemba Empat.

Oliver, \& Richard, I. (1996). Satisfaction. McGrawHill.

Oliver, \& Richard, L. (1997). Satisfaction: Abehavioral Perspective on the Customer. Mc Graw Hill.

Othman, A., \& Owen, L. (2001). Developing on Instrument to Measure Service Quality (SQ) in Islamic banking. Internatioanl Journal of Islamic Financial Service.

Parasurahman, A., Berry, L., \& Zeithaml. Research Note More Improving SQ Management. Journal Retailing.

Pane, A. (2001). The Essence of Service Marketing.
Jakarta: Pemasaran Jasa.

Rangkuty, F. (2002). Riset Pemasaran. Jakarta: Gramedia Pustaka Utama.

Rangkuty, F. (2017). Customer Care Excellence. Jakarta: Gramedia.

Santoso, S. (2002). Statistik Non Parametrik. Lekmedia Komputindo.

Tjiptono, F. (2001). Manajemen Jasa. Andi Offset. Valarie, A. Z., Leonar, I. B., \& Parasurahman. The Nature and Determinant of Customer Expectation of Sevice. Journal of Academy of Marketing Science.

Zeithaml, V. A., \& Mary, J. B. (1996). Service Marketing. The Mcgraw Hill.

Zeithaml, V. A., \& Bitner, M. J. (2000). Service Marketing: Integrating Customer Focus Acoss The Firm. Mcgraw Hill. 